\title{
Right to Self-Determination up to What Point?
}

\section{Bara $\mathrm{J}^{1}$ and Bara $\mathrm{B}^{2 *}$ \\ ${ }^{1}$ Department of Criminal Law, Law Faculty, University of Tirana, Albania \\ ${ }^{2} J u d i c i a l$ and Documentation Department, Constitutional Court of Albania, Albania}

*Corresponding author: Brunilda Bara, Judicial and Documentation Department, Constitutional Court of Albania, Deshmorete Kombit Blvd, Nr. 26, Tirana, Albania, Tel: +35542232373; Email: bruna.bara@gjk.gov.al

\section{Mini Review \\ Volume 2 Issue 1}

Received Date: October 23, 2019

Published Date: November 15, 2019

DOI: $10.23880 / a b c a-16000109$

\section{Abstract}

The principle of self-determination is prominently embodied in Article I of the Charter of the United Nations. The principle was incorporated into the 1941 Atlantic Charter and the Dumbarton Oaks proposals which evolved into the United Nations Charter. Essentially, the right to self-determination is the right of a people to determine their own destiny. Such principle allows a people to choose their own political status and to determine their own form of economic, cultural and social development in medical law, the right to self-determination is strictly connected with the autonomy of the patient, which places as the center stone the respect for competent decisions by adult patients and the right of the people to decide over their own bodies. Bodily integrity in courts' jurisprudence all over the world has been applied to wide range of human rights violations such as physical violence, ranging from corporal punishment to forced medical treatment, abortion, end of life decisions, etc. But when it comes to self-determination in medical cases, how free are we really, as individuals, to decide over our own bodies? This article aims to answer this question through courts' case law on different aspects of patient autonomy, bodily integrity and the right to self-determination.

Keywords: Self-Determination; Autonomy; Bodily Integrity; Rights; Case-Law

Abbreviations: AMA: American Medical Association; ECHR: European Court of Human Rights; PDOC: Prolonged Disorders of Consciousness; UNPO: Unrepresented Nations \& Peoples Organization.

\section{Introduction}

Life, liberty and the pursuit of happiness are selfevident, undeniable truths provided by the Declaration of Independence of the United States of America. At the center of these rights is the right of people to live their life the way they want. Liberty has a very broad meaning and it includes the right of the people to be free from interference, the right to be secure in their persons, houses, papers, and effects, against unreasonable searches and seizures, the right to move freely, freedom of religion, freedom to decide over one's own body, freedom to consent or refuse, freedom to determine the course of their life and well-being in pursuit of their happiness in life, based on the degree of satisfaction that people experience and value about their lives as a whole, etc [1-3]. 


\section{Annals of Bioethics \& Clinical Applications}

The best way to better understand one's right to selfdetermination in medical cases and the ethical questions it raises is through court's case-law and the way different courts have dealt with such right.

\section{Case-Law on the Right to Self- Determination}

\section{United States of America Case-Law}

The Constitution of the United States of America (USA) does not specifically provide individual's right to bodily integrity. One of the early cases when the right to body integrity became part of constitutional law was Union Pacific Railway Co. v. Botsford. According to Supreme Court of the USA's decision on the case, no right is more sacred, or is more carefully guarded by the common law, than the right of every individual to the possession and control of his own person, free from all restraint or interference of others, unless by clear and unquestionable authority of law [4].

However, the right to self-determination becomes questionable in end of life cases due to competing rights: in one side the right of the person to bodily integrity and to determine the fate of its own life, on the other the right of society to protect human life as a whole, paying particular importance in this regard to vulnerable groups such as young or old age individuals, disabled persons, the prevention of suicide as a social phenomenon and the integrity of health care professionals [5].

Two landmark Supreme Court decisions in the late 1990s affirmed that the aid of a physician in ending one's life is not a right protected by the US Constitution, leaving the states to decide whether the practice should be permitted and under what circumstances. In Vacco v Quill [6] and Washington v Glucksber [7], groups of physicians and terminally ill patients challenged their states' ban on assisted suicide, arguing that patients' constitutional liberty interest requires that their physicians be able to help them decide the timing and manner of death. In 1996 and 1997, the Supreme Court rejected these arguments. The Court ruled that although patients have the right to refuse life-sustaining treatment, they do not have a Constitutional right to end their lives with physicians' assistance. According to the Court, the distinction between letting die and making that patient die is important, logical, rational, and well established: It comports with fundamental legal principles of causation and that the interest in deciding "how, rather than whether" to die does not extend to a protected right to legal assisted suicide [8].
While the right to bodily integrity and selfdetermination is hard to be determined in permanent vegetative state cases [9], it has nevertheless been brought up in many cases regarding abortions. For more than sixty years the American Medical Association (AMA) had a negative policy respecting abortion. AMA often sought the prosecution of any doctor who. Engaged in the practice of abortion, regardless of the merits of the individual situation [10]. Even nowadays, abortion continues to remain a major problem in many countries, especially those countries where religious beliefs are deeply rooted in society, as the control of human reproduction is considered to be against the will and spirit of God [11].

While the human embryo is inside a female's body, she is unable to decide over her own body. The ethical question that arises in abortion cases is at what stage the fetus acquires human status and which rights should prevail? Woman's right to self-determination or embryo's/fetus's/future human's right to life? P. ex. a Chinese zygote implanted in a Swedish woman will always be Chinese, not Swedish, because his identity is based on his genetic code, not on that of the body in which he resides [12].

While there are different views on the answer to this question, which are based on personal views, morals of society, religious beliefs, individual ore state financial situations, state aid, etc., this still remains a problem in many countries. The first decision where the Supreme Court of USA found that a woman had a constitutional right of privacy that included the right to an abortion, at least in the early stages of pregnancy was Roe v. Wade [13]. Such decision was also upheld on Planned Parenthood v. Casey [14]. In this decision the Supreme Court provided also the obligation of health care providers to inform the patient on the consequences of a medical procedure before they undergo it, so that their consent is founded on understanding of the risks.

Another ethical problem to be considered is whether forced feeding should be considered medical treatment? In case of a non-terminal illness, may a competent adult refuse force-feeding done to sustain life? In the case of Bouvia v. Superior Court (Los Angeles County) [15], Elizabeth Bouvia was a mentally competent, young, quadriplegic woman who suffered from cerebral palsy, leaving her completely bedridden and dependent on others to perform all her activities of daily living. Despite having a college degree, she was financially unable to support herself, did not have a stable living situation, and 
relied on public assistance for all aspects of her care. In 1983, at age 26, she expressed a desire to end her life. Ms Bouvia then attempted to accomplish this by selfstarvation in a California public hospital, an act which was widely publicized in the media. A California court denied Ms Bouvia judicial assistance to starve herself to death and issued a court order allowing the hospital to commence force-feeding her by inserting a nasogastric tube. Ms Bouvia sued the hospital and its staff, seeking a court order from the Superior Court of Los Angeles County, to have the nasogastric tube removed and to stop all medical measures to which she did not consent. The trial court denied Ms Bouvia's request, stating that her prognosis justified the state's interest in preserving her life. Ms Bouvia appealed. The appellate court held that a patient's right to self-determination regarding medical treatment is based upon the patient being mentally competent and able to understand the consequences of withdrawal or refusal of care; that patient's interests and desires are the key ingredients of the decision-making process and that, as an important component to one's perception of a high quality of life the decision to forgo medical treatment belonged solely to Ms Bouvia. According to the decision of the court, an individual has a fundamental right to refuse medical treatment; (2) such rights supersede the state's interests; (3) quality of life is a valid and essential consideration; and (4) fulfilling the patient's desire to refuse treatment is not equivalent to assisting the patient in committing suicide [16].

\section{European Court of Human Rights' S Case Law}

The right to self-determination has also been reviewed by the European Court of Human Rights (ECHR). According to ECHR case-law, such right is embodied in Article 2 of the European Convention of Human Rights, as well as Article 8 of the European Convention of Human Rights $[17,18]$.

The right to life was first discussed by the ECHR in Pretty v. The United Kingdom [19]. The case concerned dying of motor neurone disease who requested the help of her husband to commit suicide as she was unable to do it herself. While it was not a crime to commit suicide in UK, assistance to commit suicide was. As the authorities refused her request, the applicant complained that her husband had not been guaranteed freedom from prosecution if he helped her die. ECHR held that while the Convention recognizes a right to life, it doesn't recognize a right to die. The Court also noted that there was no violation of applicant's right to prohibition of torture (Article 3 of ECHR) and neither Article 8.
In Haas v. Switzerland [20], concerning a sick person's wish to commit suicide by obtain a lethal substance (sodium pentobarbital) without a prescription, the Court held that even assuming that States had a positive obligation to take measures to facilitate suicide in dignity, the Swiss authorities had not breached that obligation in the applicant's case and, as a result, there was no violation of Article 8 of ECHR.

In Koch v. Germany [21], the case concerned a quadriplegic woman who, unable to obtain a lethal dose of a drug that would have enabled her to commit suicide in Germany, went to Switzerland where such procedure is allowed. The application with ECHR was filed by her husband. In this case, the Court found a violation of Article 8 of the Convention, in respect of the German courts' refusal to examine the merits of his complaint, considering the exceptionally close relationship between the applicant and his wife.

In Lambert and Others v. France [22], the applicants parents and half-brother and a sister of a tetraplegic applicant, complaint in particular about the medical record drawn to discontinue applicant's artificial nutrition and hydration. The Court held that there was no violation of Article 2 of ECHR as there was no consensus among the Council of Europe member States in favor of permitting the withdrawal of life-sustaining treatment and the states enjoy a margin of appreciation in this regard.

With regard to abortion issues, many of the cases before the ECHR involve countries such as Ireland and Poland, where religion continues to have an impact on the legislature and the case-law of the countries. In A., B. and C. v. Ireland [23], the case concerned 3 women living in Ireland, who became pregnant unintentionally. They complained that, because of the impossibility of obtaining a legal abortion in Ireland, they had to go to the United Kingdom for an abortion and that the procedure was humiliating, stigmatising and risked damaging their health. One of the applicants in particular, in remission from a rare form of cancer and unaware that she was pregnant underwent checkups contraindicated in pregnancy. She understood that her pregnancy could provoke a relapse and believed that it put her life at risk. The Court found a violation of Article 8 of the ECHR regarding the woman in remission from cancer, but no violation regarding the other women.

In P. and S. v. Poland [24], the case concerned the difficulties encountered by a teenage girl, who had 
become pregnant as a result of rape, in obtaining access to an abortion, in particular due to the lack of a clear legal framework, procrastination of medical staff and also as a result of harassment. The Court held that there had been a violation of Article 8 (right to respect for private and family life).

In Tysiac v. Poland [25], the case concerned a pregnant woman from Poland, diagnosed with a severe eye disease, tried to get an abortion to avoid an escalation of her disease. Her requests were rejected by several medical doctors and she underwent labor of her third child. Her condition later deteriorated, and she sued one of the doctors. Her criminal lawsuits were rejected in Poland and the case was appealed to the European Court of Human Rights. The Court held that there had been a violation of applicant's right to respect for private and family life, as the applicant had been denied access to an effective mechanism capable of determining whether the conditions for obtaining a legal abortion had been met.

In R.R. v. Poland [26], the case concerned a woman who was deliberately refused genetic tests during her pregnancy by doctors who were opposed to abortion. The applicant complaint of a violation of Articles 3 (ECHR, Art.3 - Prohibition of torture) and 8 of the ECHR [27]. The Court found a violation of both Articles.

Another ECHR's case worth mentioning regarding selfdetermination is A.-M.V. V. Finland [28], concerning restrictions on the right to self-determination of an intellectually disabled person. In this case, the applicant, an intellectually disabled young man, requested to be allowed to move from his home town in the south of Finland to a remote area in the north of the country to live with an elderly couple who were his former foster parents. That was his wish. However, the applicant's court appointed mentor or guardian considered that the move was not in his best interests. The applicant brought proceedings aimed at a partial change in his mentor arrangements so as to allow him to make his own decision on the matter. The Finnish courts, having heard the applicant, several witnesses and expert evidence on the applicant's cognitive ability, and taking all relevant circumstances into account, concluded that the applicant was clearly unable to understand the significance of his project. The courts upheld the mentor's assessment and refused the applicant's request to have the mentor arrangements modified. The Court accepted that there had been an interference with the applicant's right to selfdetermination as an aspect of his right to respect for his private life. However, the decision to give precedence to the mentor's assessment over the applicant's own wish was not a disproportionate restriction of his right, having regard to the aim pursued - the protection of the applicant's health in the broader sense of his well-being.

\section{Other Recent Cases from Different Countries on the Right to Self-Determination}

In recent years, many countries have been involved in the promotion of individual's right to self-determination, autonomy and bodily integrity, though legislative measures.

In this regard, the case of Carter $v$ Canada (AG) [29], in Canada was a landmark Supreme Court of Canada decision where the prohibition of assisted suicide was challenged as contrary to the Canadian Charter of Rights and Freedoms by several parties, including the family of Kay Carter, a woman suffering from degenerative spinal stenosis, and Gloria Taylor, a woman suffering from amyotrophic lateral sclerosis. In a unanimous decision on February 6, 2015, the Court struck down the provision in the Criminal Code, thereby giving Canadian adults who are mentally competent and suffering intolerably and enduringly the right to a doctor's assistance in dying. This ruling overturned the Supreme Court's 1993 ruling in Rodriguez $v$ British Columbia (AG), which had denied a right to assisted suicide.

The court suspended its ruling for 12 months, with the decision taking effect in 2016, to give the federal government enough time to amend its laws. In January 2016, the court granted an additional four-month extension to its ruling suspension to allow time for the newly elected federal Liberal government to consult with Canadians on drafting a law to comply with the ruling. As an interim measure, it also ruled that provincial courts could begin to approve applications for euthanasia until the new law passed [30].

In An NHS Trust and others (Respondents) v Y (UK) [31], concerning a request of NHS Trust to remove, from a man with severe cerebral hypoxia and extensive brain damage, the feeding tube keeping him alive, the Supreme Court of the United Kingdom concluded in clear terms that there was no requirement either at common law or under the ECHR for court approval to be sought when withdrawing treatment from a PDOC (prolonged disorders of consciousness) patient [32].

The Constitutional Court of Italy is at present considering a case filed by the Appeal's Court of Milano [33], on Article 580 of the Italian Criminal Code which 
criminalizes assisted suicide. Pending the filing of the sentence, the Press Office has announced that the Court has found that, under certain conditions, a person who facilitates the execution of assisted suicide, autonomously and freely formed by a patient kept alive by life support treatments and suffering from an irreversible pathology, source of physical or psychological suffering that he considers intolerable but fully capable of making free and conscious decisions, is not to be held responsible or punished under Article 580 of the Criminal Code. The case concerned $\mathrm{Dj}$ Fabiano Antoniani (blinded and quadriplegic after a car accident) who, with the help of Marco Cappato, treasurer of the Luca Coscioni association (who accompanied Fabiano) on 27 February 2017 committed assisted suicide in a Swiss clinic [34].

\section{Conclusion}

The right to self-determination, while of paramount importance with regard to individual's rights and freedoms, must be determined in the light of the circumstances of the case. The answer to selfdetermination cases is not just as simple as a "yes" or "no". The approach must be more holistic, taking into consideration the special circumstances of each case.

Recent developments and the case-law of many countries in the world show a tendency to recognize and guarantee many of the rights that before were very restricted. Obviously constitution and laws are living instruments, and as such they should reflect the changes in the perception of society as a whole. Nevertheless, apart from taking positive steps to ensure such rights, the states must make sure that these rights are effectively guaranteed and protected, making sure to punish anyone who tries to abuse of profit from them.

\section{References}

1. (1945) Charter of the United Nations and Statute of the International Court of Justice. San Francisco, pp: $1-54$.

2. UNPO's (2017) Self-determination. Unrepresented Nations \& Peoples Organization.

3. Olmstead V (1928) Certiorari to the Circuit Court of Appeals for the Ninth Circuit. October Term United States, pp: 438-488.

4. Dallas GM, Stewart A, Smaltz HN, McCarthy JA, Howard Benton Lewis (1893) Department of

Bara J and Bara B. Right to Self-Determination up to What Point?. Ann Bioethics Clin App 2019, 2(1): 000109.
Evidence Union Pacific Railway Co. v. Botsford. Supreme Court of the United States 6: 550-556.

5. Steinberg DR (1988) Limits to death with dignity. Harvard Journal of Law and Technology 1: 130-138.

6. Quill VV (1997) Certiorari to the United States Court of Appeals for the Second Circuit, pp: 793-810.

7. Washington, Glucksberg V (1997) Certiorari to the United States Court of Appeals for the Ninth Circuit, pp: 702-792.

8. Spence RA, Blanke CD, Keating TJ, Taylor LP (2017) Responding to Patient Requests for Hastened Death: Physician Aid in Dying and the Clinical Oncologist. J Oncol Pract 13(10): 693-699.

9. (1990) Cruzan v Director, Missouri Department of Health, 497 U S 261. Justia US Supreme Court.

10. (2005) In re Quinlan. Justia US law.

11. Clark TC (1969) Religion, Morality, and Abortion: A Constitutional Appraisal. Loyola of Los Angeles Law Review 2(1): 1-11.

12. Ibid.

13. (2000) Pro-Life Answers to Pro-Choice Arguments. Randy Alcorn, pp: 17-40.

14. Wade RV (1973) Appeal from the United States District Court for the Northern District of Texas, pp: 113-178.

15. (1992) Certiorari to the United States Court of Appeals for the Third Circuit, pp: 833-1002.

16. (1986) Bouvia v Superior Court.

17. Liang BA, Lin L (2005) Bouvia v Superior Court: Quality of Life Matters. Ethics Journal of the American Medical Association 7(2): 177-182.

18. Article 2-Right to life (1950) The European Convention on Human Rights, pp: 6.

19. Article 8-Right to respect for private and family life (1950) The European Convention on Human Rights, pp: 11.

20. Pretty V The United Kingdom (2002) Cour Europeenne Des Droits De L'homme European Court of Human Rights, Strasbourg, pp: 1-42. 


\section{Annals of Bioethics \& Clinical Applications}

21. Haas v Switzerland (2011) First section Judgment. The European Convention on Human Rights.

22. Koch v Germany (2012) Former Fifth Section. European Court of Human Rights Court Europeenne Des Droits Del' Homme.

23. Lambert and Others v France (2015) Grand Chamber. European Court of Human Rights Court Europeenne Des Droits Del' Homme.

24. A B and C v Ireland (2010) Grand Chamber. European Court of Human Rights Court Europeenne Des Droits Del' Homme.

25. (2013) P and S v Poland. Global Health and Human Rights Database.

26. Tysiac v Poland (2007) Ensuring Effective Access to Legal Abortion. Center for Reproductive Rights.

27. RR v Poland (2011) Forth Section Judgment. European Court of Human Rights Court Europeenne Des Droits Del' Homme.
28. Article 3-Prohibition of torture (1950) The European Convention on Human Rights, pp: 7.

29. AMV v Finland (2017) Essex Chambers. European Court of Human Rights.

30. Canada CV (2016) Supreme Court of Canada.

31. (2016) Canada Legalizes Physician-Assisted Dying. The Two-Way.

32. The Supreme Court of The United Kingdom, Decided cases (2018) An NHS Trust and others (Respondents) v Y (UK). UKSC 46: 2-46.

33. Tony Nicklinson, Paul Lamb (2014) - R on the application of Nicklinson and Lamb v Ministry of Justice. On appeal from [2013]. EWCA Civ 961, UKSC 38.

34. Grazia Longo (2019) The Consulta says yes to assisted suicide, a historical verdict. Lastampa. 